\title{
ANALYSIS OF HEAVY METAL CONTENT OF CADMIUM (Cd) IN MILKFISH (Chanos chanos Forsk) FROM MILKFISH FARMS IN BIMA BAY
}

\author{
Bukhari Muslim, Khairuddin*, M. Yamin, and Kusmiyati \\ Biology Education Study Program, Faculty of Teacher Training and Education, University of Mataram, \\ Mataram, Indonesia \\ *Email: khairuddin.fkip@unram.ac.id
}

\author{
Accepted: January 03, 2022. Approved: January 14, 2022. Published: January 17, 2022
}

\begin{abstract}
The research aims to analysis of the content of heavy metals cadmium (Cd) in milkfish (Chanos chanos Forsk) from the encroachment of Bima bay at year 2020. The benefit of this study is to provide information related to the content of heavy metals cadmium (Cd) in milkfish (Chanos chanos Forsk) and protect the community or consumers from heavy metal contaminants. The research was conducted in Bima Bay, namely in 2 research locations, namely Malay village, Bima City, and Palibelo, Bima Regency. This type of research is descriptive explorative research - sampling techniques using purposive sampling. Samples of milkfish were taken directly on the pond area of 3 heads in each location. Then the sample is put in the sample box that has previously been washed clean. The research samples were then analyzed of the content of heavy metal cadmium (Cd) using Atomic Absorption Spectrophotometer tool. The results showed that at the palibelo research site, Bima Regency in PB 1 samples contains cadmium (Cd) of $30 \mathrm{ppm}$, PB 2 samples of $40 \mathrm{ppm}$, and PB 3 samples of $10 \mathrm{ppm}$. Furthermore, at the location of Malay village, Bima City on KM 1 sample of $30 \mathrm{ppm}$, on KM 2 sample of $40 \mathrm{ppm}$, and KM 3 sample of $20 \mathrm{ppm}$. The content of heavy metal cadmium (Cd) in milkfish (Chanos chanos forsk) from Bima Bay exceeds the threshold by BPOM Regulation No. 5 of 2018 is $0.1 \mathrm{ppm}$. The presence of heavy metal content cadmium $(\mathrm{Cd})$ that exceeds this threshold indicates that the waters of Bima Bay have been contaminated by heavy metals Cadmium $(\mathrm{Cd})$.
\end{abstract}

Keywords: Cadmium (Cd), Milkfish, Bima Bay.

\section{INTRODUCTION}

Milkfish (Chanos chanos Forsk) is an important economic value fish widely cultivated in brackish water ponds and is a consumption fish in great demand by the community, especially in Southeast Asia. Milkfish cultivation in ponds is overgrowing in almost all of Indonesia. Bima Regency is one of the Province of West Nusa Tenggara (NTB), which can develop a relatively large pond cultivation business (milkfish ponds), one of which is in Woha District. Woha District is one of the sub-districts with a large pond area and a milkfish production center, where the number of Fishery Households (RTP) is 738 RTP. In 2013, the ponds area in Woha District was $1,163.41$ ha with a total milkfish production of 932.63 tons spread over five villages, i.e., Talabiu Village, Penapali Village, Dadibou Village, Donggobolo Village, and Pandai Village [1].

Many factors determine the success of a milkfish pond business, one of which is feed. Feed is the key that determines the success of milkfish cultivation because, without good and appropriate feeding, milkfish cultivation will be complicated to succeed [2]. Urea fertilizer is one of the most frequently used fertilizers in the plant cultivation process. Besides being beneficial for plants, it turns out that urea fertilizer is also helpful for fish growth and development. The safety of inorganic (chemical) fertilizers is still not guaranteed, and excessive use of fertilizers will hurt the organisms being cultivated [3].
Fertilizers are common in agriculture but are rarely seen in fisheries. The use of fertilizer in fish ponds before use is very good for the growth of the fish themselves. Giving fertilizer to the pond can stimulate the formation of plankton in the water. The cultivation pattern of pond farmers only rely on inorganic fertilizers, i.e., urea fertilizer and TSP fertilizer. One of the mixed ingredients for making fertilizer is Cadmium (Cd) [4]. Chemical fertilizers (inorganic) will increase agricultural and aquaculture yields with nitrogen content needed by the soil. However, the use of this fertilizer causes environmental degradation (pollution) on agricultural land [5].

The high market demand has become a fertile field for industrial development. The 20th century until now is referred to as the period of industrialization, marked by the proliferation of industrial activities to meet various human needs. Many economic benefits result from a series of production processes, distribution to the hands of consumers. However, the benefits derived from these industrial activities have ecological consequences; the high level of environmental pollution during the industrialization period [6].

Heavy metals are one of the causes of environmental pollution. Heavy metal is the name given to toxic metal elements because they have a heavy density or atomic mass [7]. Heavy metals, including Lead $(\mathrm{Pb})$, Cadmium $(\mathrm{Cd})$, Manganese (Mn), and Arsenic (As) are constituents that can naturally be found in the earth's crust [8]. However, 
the natural formation of heavy metals is also followed by decomposition into other soluble or harmless forms through geochemical cycles and biochemical balances [9].

Basically, heavy metals are needed in the metabolism of living things in varying amounts [9]. Several types of microbes utilize metals as a source of nutrients to support cell survival and growth, for example in Trichoderma asperellum which shows the ability to reduce Cadmium content in its growth medium, Aspergillus niger decomposes silver and Basidomycetes absorb uranium from its environment [10]. Toxic properties of metals if exposure to heavy metals takes place continuously. It will cause bioaccumulation of heavy metals in waters [11]. With the damage caused by heavy metals which are quite dangerous, this has attracted a lot of attention from the world community, and has raised awareness of the dangers of heavy metals for the survival of biota on earth.

Pollution can occur in the water, soil or air environment. Disposal of liquid waste without going through special treatment for waste treatment results in high concentrations of toxic substances that enter aquatic bodies. Toxic substances come from chemical pollutant substances that do not occur naturally in aquatic ecosystems. Toxic pollutants include herbicides, industrial waste and pesticides. Pollutants produced by industry contain hazardous materials such as Lead $(\mathrm{Pb})$, Copper $(\mathrm{Cu})$, Cadmium $(\mathrm{Cd})$, and Manganese ( $\mathrm{Mn})$ [12]. In addition, the pollutant produced from household domestic waste is also quite high, in line with the increasing rate of population growth [13].

Coastal resources play an important role in supporting' regional and national economic development to increase foreign exchange earnings, employment, and income of the population. These coastal resources have a comparative advantage because they are available in large and diverse quantities and can be utilized with relatively low exploitation costs, so as to create a competitive supply capacity. However, behind this potential, the existence of resources is often threatened due to development that is not environmentally sound [14].

The marine environment, especially coastal areas, has experienced threats from human activities directly and indirectly in the upstream areas. Overexploitation has caused damage to several coastal ecosystems such as seagrass ecosystems with indicators of the scarcity of several marine biota such as fish, mollusks, sea-urchins and sea cucumbers associated with seagrass in coastal waters of East Lombok [15]. Another threat to the sustainability of the marine environment, especially in coastal areas is the problem of pollution. In Bima Bay, heavy metal contamination was also found. This was shown by the results of research [16] which found heavy metals Cadmium (Cd), Mercury ( $\mathrm{Hg}$ ) and Lead $(\mathrm{Pb})$ in the bivalves' network taken from the sediments of Bima Bay. This is because the marine environment is an estuary or a target for waste disposal, so it is easily contaminated by heavy metals such as mercury $(\mathrm{Hg})$, lead $(\mathrm{Pb})$, and cadmium (Cd)[17].

In Indonesia itself, this environmental pollution has been regulated in Law No. 23 of 1997 which discusses environmental management, PP RI No. 82 of 2001 on managing water quality and controlling pollution in waters and the maximum limit of heavy metals is regulated in Regulation of the Head of BPOM No. 23 of 2017 concerning the maximum limit of heavy metal contamination in processed foods.

However, these statutory instruments have not been effective in controlling pollution in Indonesian waters. In the case found in Bima Bay some time ago, it was evidence of the low awareness of protecting the environment. According to an analysis by [18] that the metal content of bioindicator plants/mangroves in Bima Bay in each mangrove species (Sonneratia alba), $\mathrm{Cd}$ in mangrove leaves (Sonneratia alba) was $0.24 \mathrm{ppm}$, and $0.19 \mathrm{ppm}$ in roots and Cadmium $(\mathrm{Cd})$ content in leaves of Ryzophora apiculata is $0.41 \mathrm{ppm}$ and in roots is $0.18 \mathrm{ppm}$. Similar cases were also found in the waters of Jakarta Bay. The area is functioned as a place for industry, recreation and fishing. At the same time, it is also used as a dumping ground for garbage and industrial waste. The pollutants detected were Lead $(\mathrm{Pb})$ of 8.49-31.22 ppm, Copper $(\mathrm{Cu})$ of 13.81-193.75 ppm, and Cadmium $(\mathrm{Cd})$ of $<0.001-0.47$ ppm [19].

According to [20] Cadmium (Cd) is a heavy metal with the second highest toxicity number seven according to the ATSDR (Agency for Toxic Substances and Disease Registry) ranking. In the industrial sector, heavy metals are needed as raw materials or as additional catalysts. Several industries that contribute Cadmium $(\mathrm{Cd})$ to water bodies are metal coating, paint industry, metallurgy, oil disposal, fossil fuel combustion, mining, iron ore washing, pesticides, dyes, and batteries [21]. With the concentration of Cadmium $(\mathrm{Cd})$ which is too high, it will shift the geochemical and biochemical equilibrium which is the natural metal decomposition mechanism.

The concentration of pollutants is said to be high if it exceeds the threshold, so it has the potential to cause harm to the environment [22]. Cadmium (Cd) concentrations that exceed the threshold can interfere with hemostasis in aquatic organisms, so that it can cause organ damage, including disorders of the liver, blood pressure, lungs, bone fragility, kidney system, digestive glands, and death [6]. The emergence of pathology in aquatic organisms due to contact with pollutant substances is the basis for determining aquatic biota as bioindicators of water pollution status. 
Various organisms are used as bioindicators of cadmium $(\mathrm{Cd})$, including groups of bivalves and invertebrates [23]. Cadmium $(\mathrm{Cd})$ contained in the aquatic environment will also enter the body of aquatic biota and accumulate continuously due to long-term exposure. The presence or absence of cadmium $(\mathrm{Cd})$ in the body of the biota is an indicator of cadmium $(\mathrm{Cd})$ contamination in water bodies. In addition to aquatic invertebrates, fish which are members of vertebrates can also be used as bioindicators [24].

Fish are aquatic organisms that can move quickly. Fish, in general, can avoid the effects of water pollution. If the fish's body contains high levels of heavy metals and exceeds the predetermined normal limits, it indicates that environmental pollution has occurred. Heavy metals enter the body tissues of fish through several routes, i.e., the digestive tract, respiratory tract, and penetration through the skin [25]. The number of heavy metals absorbed and distributed in fish depends on compounds and concentrations of pollutants, microorganism activity, sediment texture, and the types and elements of fish that live in the environment. The average value of Lead levels in fish determined by SNI and WHO is 0.3 ppm.

The maximum Cadmium (Cd) level set by BPOM is $0.1 \mathrm{mg} / \mathrm{kg}$. Based on the above background, the authors conducted a study to know the heavy metal content of Cadmium (Cd) in milkfish (Chanos chanos Forsk) in the milkfish aquaculture area of Bima Bay.

\section{RESEARCH METHOS}

This research was conducted in January - June 2021. This research was conducted in the Bima Bay area and was divided into 2 locations, i.e., the Malay Village, Bima City and Palibelo Village, Bima Regency. Determination of the location based on the existence of milkfish ponds that were still actively used by the community.

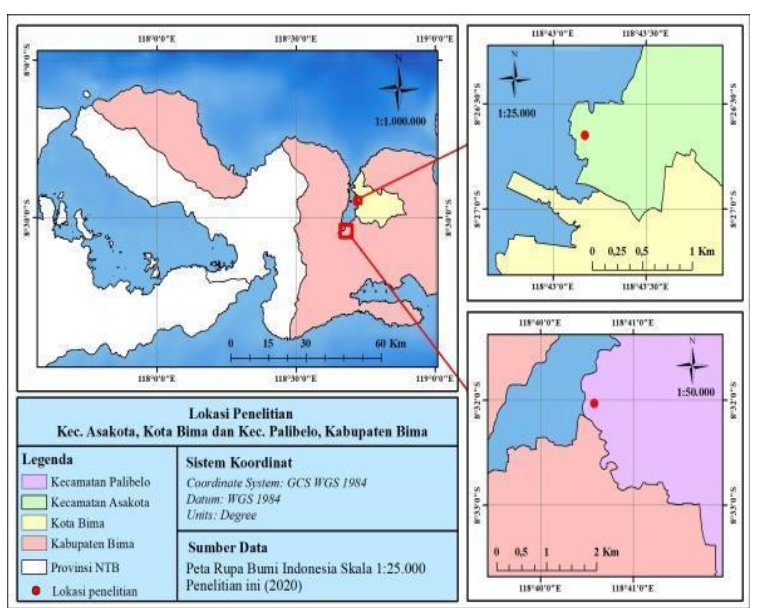

Figure 1. research location map

\section{Data collecting method}

The sampling technique used in this study was purposive sampling. The reason for using purposive sampling is because not all samples have criteria that match the phenomenon of the study. The criteria in question are the weight and age of milkfish (Chanos chanos Forsk), observations by recording the results were conducted with the help of an electronic recorder for temperature and salinity. Then, the milkfish samples were analyzed in the analytical chemistry laboratory at the University of Mataram.

\section{Data analysis method}

The analysis process began with the selection of samples of milkfish (Chanos chanos Forsk), milkfish used as samples in this study are milkfish which are ready to harvest which have reached the age of 4-5 and milkfish which weighs 300-400 grams/head, [26]. The next stage is surgery, the fish was taken and surgery was conducted starting from the anal to the upper abdomen and then the meat was taken as the target organ for testing [27]. The samples, then, put in a cup, and weighed of $0.5 \mathrm{~g}$ of the wet sample. Furthermore, analysis of the content of Cadmium (Cd) with Atomic Absorption Spectrophotometry (AAS), Wet Destruction Stage on Samples Destruction was a process of degradation of sample organic matter by utilizing strong acid liquid; according to [28], HNO3 an acidic material that can be used as a destructive agent. The stages of destruction can be explained as follows: 0.5 grams of sample in a Kjeldahl flask, added 1 gram of catalyst (a mixture of $\mathrm{Na} 2 \mathrm{SO} 4$ and $\mathrm{CuSO} 4$ ratio 2:1), added as much as $6 \mathrm{~mL}$ of $\mathrm{H} 2 \mathrm{SO} 4$ solvent, heated with a Kjeldahl term device at $350^{\circ} \mathrm{C}$ for $2-3$ hours until the solution is clear, stopped heating then cooled.

The next stage was the preparation stage for the calibration curve. 1000 ppm Cadmium (Cd) standard solution was diluted to make a calibration curve which refers to the method of making Cadmium (Cd) curve by [29] as follows: of 1000 ppm standard solution of Cadmium $(\mathrm{Cd}), 0.1 \mathrm{ml}$ is taken using a pipette, put into a $100 \mathrm{ml}$ volumetric flask, then distilled water is added up to the mark and homogenized, so a standard solution of Cadmium (Cd) $1 \mathrm{ppm}$ is obtained. Then, in the same way a dilution of a standard solution of Cadmium (Cd) $1 \mathrm{ppm}$ is made to a concentration of $0.02 \mathrm{ppm}$; 0.04 ppm; 0.05 ppm; 0.06 ppm; 0.08 ppm; and 0.09 ppm according to the dilution equation. In the manufacture of fish rearing media, the standard solution that has been made, each absorption is measured using an Atomic Absorption Spectrophotometer with the following steps: A computer is used to measure the Atomic Absorption Spectrophotometry (AAS) (Shimadzu AA-7000), the cathode lamp of the Atomic Absorption Spectrophotometry (AAS) test is turned on and the position of the lamp is adjusted so that maximum 
absorption is obtained, the standard solution is aspirated and then the measurement of the atomic absorption readings on the Atomic Absorption Spectrophotometry (AAS) Test is obtained. The data obtained was in the form of heavy metal content of Cadmium (Cd). The sample was in ppm (parts per million), the data obtained was processed descriptively and the data was presented in the form of tables and graphs based on the results of Atomic Absorption Spectrophotometry (AAS) or AAS analysis [30].

\section{RESULTS AND DISCUSSION}

The results showed that the heavy metal content of Cadmium (Cd) in milkfish (Chanos chanos Forks) tissue in Bima Bay at the Palibelo research location, Bima Regency in sample PB1 contained Cadmium (Cd) of $30 \mathrm{ppm}$, in sample PB2 of $40 \mathrm{ppm}$. and in the sample PB3 of $10 \mathrm{ppm}$. Furthermore, at the location of the Malay Village, Bima City, the sample KM1 was 30 ppm, the sample KM2 was 40 ppm and the sample KM3 was 20 ppm.

From these data it is clear that the $\mathrm{Cd}$ content is high because it is above the permissible threshold according to the maximum permissible standard, 0.1 $\mathrm{mg} / \mathrm{kg}$, as stated in BPOM Regulation No. 5 of 2018.

Cadmium $(\mathrm{Cd})$ concentrations that exceed the threshold can interfere with hemostasis in aquatic organisms, so, it can cause organ damage, including disorders of liver, blood pressure, lungs, bone fragility, kidney system, digestive glands, and death [6].

The results are thought to be influenced by the environment and location, in two Palibelo research locations, Bima Regency and Melayu Village, Bima City, which is adjacent to agricultural land and there are several rivers that flow from upstream to downstream of Bima Bay, including the Palibelo river, the Bolo Subdistrict river, Donggo Subdistrict River, Padolo River in the city of Bima and several other rivers that contribute to the presence of heavy metal Cadmium (Cd) from agricultural areas to the Bima Bay area which is commonly used by residents as milkfish ponds. Disposal of industrial waste is the main cause of heavy metal pollution on agricultural land and aquaculture because it contains the highest heavy metal elements compared to other pollutant sources.

The continuous increase in the use of pesticides and inorganic fertilizers over a long period of time causes Cadmium contamination in agricultural and aquaculture lands to increase. The research location is also close to residential areas which is a source of pollution in fish ponds, this is in line with the opinion [31] which states that sources of Cadmium and other heavy metals pollution are residential areas and human activities using industrial products. It is very possible that contamination of heavy metal Cadmium is because the activities of pond farmers put fertilizer into the ponds; there is a phenomenon in the fish pond farming community in Bima where the fish pond farmers before entering the milkfish seeds, the pond is first filled with urea fertilizer which is known to contain heavy metal Cadmium (Cd). It is intended that the formation of plankton in the water and the growth of algae as feed for the milkfish thrives. The use of fertilizers is common in the agricultural world, but is still rarely seen in the world of fisheries, because the application of fertilizers in ponds can stimulate the formation of plankton in the water and the growth of algae in the waters [4].

Contribution of contamination from agricultural waste, household waste and industrial waste is quite large because the management has not been conducted properly according to waste management standards. Some of the residential industrial waste and household waste are dumped into rivers and enter through the irrigation network to agricultural land. Disposal of household waste into rivers occurs in almost all parts of Indonesia.

In many places, such as the bay, there is heavy metal contamination, such as in the waters of Kendari Bay [32]. Community and industrial activities as sources of water pollution need attention in order to reduce the burden of waste entering the waters, the impact on organisms, thus, can be minimized [29], and also because based on the results of this study, the $\mathrm{Cd}$ level has exceeded the threshold set by BPOM.

Heavy metals become a hazard due to the bioaccumulation system. Bioaccumulation is an increase in the concentration of chemicals in the body of living things from time to time, compared to the concentration of chemicals in the environment. The entry of heavy metals in the body such as Lead $(\mathrm{Pb})$, Mercury $(\mathrm{Hg})$, Arsenic (As), and Cadmium (Cd) will have a very negative impact on the body because the body will experience disturbances. In the body, Cadmium is transported to the liver by the blood. It will form bonds with proteins and be transported to the kidney and accumulate in the kidneys. If contaminated, it will interfere the kidney function, and kidney damage can cause diarrhea, abdominal pain and vomiting, bone fractures, reproductive failure and even infertility, damage to the central nervous system, damage to the immune system, psychological disorders, DNA damage or cancer.

\section{CONCLUSION}

The content of heavy metal Cadmium $(\mathrm{Cd})$ in milkfish meat (Chanos chanos Forsk) from Bima Bay, at the Palibelo research location, Bima Regency in sample PB1 contained Cadmium (Cd) of $30 \mathrm{ppm}$, in sample PB2 of $40 \mathrm{ppm}$ and the sample PB3 of 10 ppm. Furthermore, at the Malay Village, Bima City, the sample KM1 was 30 ppm, the sample $\mathrm{KM} 2$ of was $40 \mathrm{ppm}$, and the sample KM3 was 20 ppm. The heavy metal Cadmium (Cd) content in 
milkfish (Chanos chanos Forsk) from Bima Bay exceeds the threshold based on BPOM regulation No. 5 of 2018, which is $0.1 \mathrm{ppm}$. The presence of heavy metal content of Cadmium $(\mathrm{Cd})$ that exceeds this threshold indicates that the waters of Bima Bay have been contaminated by heavy metal Cadmium (Cd).

\section{THANK-YOU NOTE}

The authors would like to thank the supervisor, Drs. H. Khairuddin, M.Eng. and Mr. Drs. H. M. Yamin, M.Si., and all parties who have helped in this research process.

\section{REFERENCES}

[1] Kusumayadi, F., Badar, M., Yusuf, M., Zulfikar, M., \& Iyelda, N. (2021). Pemberdayaan Masyarakat Melalui Keterampilan Inovasi Pengolahan Dendeng Ikan Bandeng Kemasan di Desa Donggobolo Kecamatan Woha Kabupaten Bima. Jurnal Dharma Jnana, 1(3), 211-219.

[2] Wahyuningsih, S. (2009). Pengaruh komposisi pakan terhadap laju pertumbuhan ikan Nila [skripsi]. Semarang: Fakultas Pendidikan Matematika dan Ilmu Pengetahuan Alam IKIP PGRI Semarang.

[3] Ariefiandi, Y. (2020). Identifikasi jenis makanan ikan palapinang (desmopuntius pentazona) yang berada di sungai Jelutung Universitas Bangka Belitung Desa Balun Ijuk (Doctoral dissertation, Universitas Bangka Belitung).

[4] Sutrisno, S., \& Kuntyastuti, H. (2015). Pengelolaan cemaran kadmium pada lahan pertanian di Indonesia. Buletin Palawija, 13(1), 83-91.

[5] Harun, M. A. (2020). Pengaruh Pupuk Organik dan Anorganik Terhadap Pertumbuhan Ikan Bandeng Chanos-chanos. SIGANUS: Journal of Fisheries and Marine Science, 1(2), 51-55.

[6] Siska, M., \& Salam, R. (2012). Desain eksperimen pengaruh zeolit terhadap penurunan limbah kadmium (Cd). Jurnal Ilmiah Teknik Industri, 11(2), 173-184.

[7] Pasaribu, C. A., \& Marbun, P. (2017). Kandungan Logam Berat $\mathrm{Pb}$ Pada Kol dan Tomat di Beberapa Kecamatan Kabupaten Karo: Heavy Metal Pb Content In Cabbage And Tomatoes In Several Districts Of Karo Regency. Jurnal Online Agroekoteknologi, 5(2), 355-361.

[8] Fan, Y., Zhu, T., Li, M., He, J., \& Huang, R. (2017). Heavy metal contamination in soil and brown rice and human health risk assessment near three mining areas in central China. Journal of healthcare engineering, 2017.

[9] Singh, R., Gautam, N., Mishra, A., \& Gupta, R. (2011). Heavy metals and living systems: An overview. Indian journal of pharmacology, 43(3), 246.

[10] Mohsenzadeh, F., \& Shahrokhi, F. (2014). Biological removing of Cadmium from contaminated media by fungal biomass of Trichoderma species. Journal of Environmental Health Science and Engineering, 12(1), 1-7.

[11] Purnamawat, F. S., Soeprobowati, T. R., \& Izzati, M. (2015). Potensi Chlorella vulgaris Beijerinck Dalam Remediasi Logam Berat Cd Dan Pb Skala Laboratorium. Bioma: Berkala Ilmiah Biologi, 16(2), 102-113.

[12] Warni, D., Karina,S., dan Nurfadillah,N. 2017. Analisis Logam $\mathrm{Pb}, \mathrm{Mn}, \mathrm{Cu}$ dan $\mathrm{Cd}$ pada Sedimen di Pelabuhan Jetty Melulabohaceh Barat. Journal Ilmiah Mahasiswa Kelautan dan Perikanan Unsyiah Vol 2 No 2:246-253.

[13] Nilasari, E., Faizal, M. F. M., \& Suheryanto, S. (2016). Pengolahan Air Limbah Rumah Tangga dengan Menggunakan Proses Gabungan Saringan Bertingkat dan Bioremediasi Eceng Gondok (Eichornia crassipes),(Studi Kasus di perumahan Griya Mitra 2, Palembang). Jurnal Penelitian Sains, 18(1), 8-13.

[14] Al Idrus, A., Ilhamdi, M. L., Hadiprayitno, G., \& Mertha, G. (2018). Sosialisasi Peran dan Fungsi Mangrove Pada Masyarakat di Kawasan Gili Sulat Lombok Timur. Jurnal Pengabdian Magister Pendidikan IPA, 1(1).

[15] Syukur, A., \& Mahrus, S. A. (2016). The potential assessment environment friendly aquaculture of small-scale fishermen as a conservation strategy seagrass beds in coastal areas of Tanjung Luar East Lombok, Indonesia. management, 19(20), 21.

[16] Khairuddin., Yamin, M., dan Syukur, A. 2016. Analisis Kandungnan Logam Berat pada Tumbuhan Mangrove Sebagai Bioindikator di Teluk Bima, 16 (2):10-22

[17] Ramli, M., Muslim, B., \& Fajriah, S. N. (2019). Integrasi Pencemaran Logam Berat dan Islam Menggunakan Metode 4-STMD. Jurnal AsSalam, 3(3), 102-115.

[18] Khairuddin., Yamin, M., dan Syukur, A. 2018. Analisis Kandungnan Logam Berat pada Tumbuhan Mangrove Sebagai Bioindikator di Teluk Bima. Jurnal Biologi Tropis, JANUARIJUNI 2018: Volume 18 (1).

[19] Rochyatun, E., \& Rozak, A. (2010). Pemantauan kadar logam berat dalam sedimen di perairan teluk Jakarta. Makara Journal of Science.

[20] Jaishankar, M., Tseten, T., Anbalagan, N., Mathew, B. B., \& Beeregowda, K. N. (2014). Toxicity, mechanism and health effects of some heavy toxicology, 7(2), 60.

[21] Rani, A., Kumar, A., Lal, A., \& Pant, M. (2014). Cellular mechanisms of cadmium-induced 
toxicity: a review. International journal of environmental health research, 24(4), 378-399.

[22] Nwani, C. D., Nwoye, V. C., Afiukwa, J. N., \& Eyo, J. E. (2009). Assessment of heavy metals concentrations in the tissues (gills and muscles) of six commercially important fresh water fish species of Anambra River South-East Nigeria. Asian Journal of Microbiology, Biotechnology and Environmental Sciences, 11(1), 7-12.

[23] Mutoharoh, I. L. (2019). Bioakumulasi paparan logam berat Cadmium (Cd) pada daging ikan Lele (Clarias sp.) (Doctoral dissertation, UIN Sunan Ampel Surabaya).

[24] Prastyo, D., \& Herawati, T. (2016). Bioakumulasi logam kromium (cr) pada insang, hati, dan daging ikan yang tertangkap di hulu sungai cimanuk kabupaten garut. Jurnal Perikanan Kelautan, 7(2).

[25] Darmono. (1995). Logam dalam sistem biologi makhluk hidup. Penerbit Universitas Indonesia.

[26] Indonesia, T. P. W. (2014). Seri Panduan Perikanan Skala Kecil Budidaya Ikan Bandeng (Chanos chanos) pada Tambak Ramah Lingkungan. Jakarta Selatan: WWF Indonesia, 54.

[27] Fernanda, L. (2012). Studi kandungan logam berat timbal $(\mathrm{Pb})$, Nikel $(\mathrm{Ni})$, Kromium $(\mathrm{Cr})$ dan kadmium $(\mathrm{Cd})$ pada kerang hijau (Perna viridis) dan sifat fraksionasinya pada sedimen laut. Skripsi, Universitas Indonesia, DepokIndonesia.

[28] Martuti, N. K. T. (2012, September). Kandungan logam berat cu dalam ikan bandeng, studi kasus di tambak wilayah Tapak Semarang. In Seminar Nasional Pengelolaan Sumberdaya Alam dan Lingkungan.

[29] Nasution, S., \& Siska, M. (2011). Kandungan logam berat Timbal $(\mathrm{Pb})$ pada sedimen dan siput Strombus canarium di Perairan Pantai Pulau Bintan. Jurnal Ilmu Lingkungan, 5(02), 82-93.

[30]Zulfiah, A., Seniwati, S., \& Sukmawati, S. (2017). Analisis Kadar Timbal (Pb), Seng (Zn) Dan Tembaga (Cu) Pada Ikan Bandeng (Chanos Chanos Forsk.) Yang Berasal Dari Labbakkang Kab. Pangkep Secara Spektrofotometri Serapan Atom (SSA). Jurnal Ilmiah As-Syifaa, 9(1), 8591.

[31] Keman, S. (1998). Pencemaran Lingkungan dan Deteksi Dininya, Seminar Sehari Tentang Efek Pence maran Lingkungan Terhadap Kesehatan Sistem Reproduksi. Surabaya: FKM Unair.

[32] Amriarni, A., Hendrarto, B., \& Hadiyarto, A. (2011). Bioakumulasi logam berat timbal $(\mathrm{Pb})$ dan seng ( $\mathrm{Zn}$ ) pada kerang darah (Anadara granosa L.) dan kerang bakau (Polymesoda bengalensis L.) di perairan Teluk Kendari. Jurnal Ilmu Lingkungan, 9(2), 45-50. 